ISSN : $1812-5379$ (Print)

ISSN : 1812-5417 (Online)

http://ansijournals.com/ja

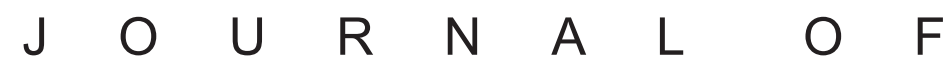 AGRONOMY
}

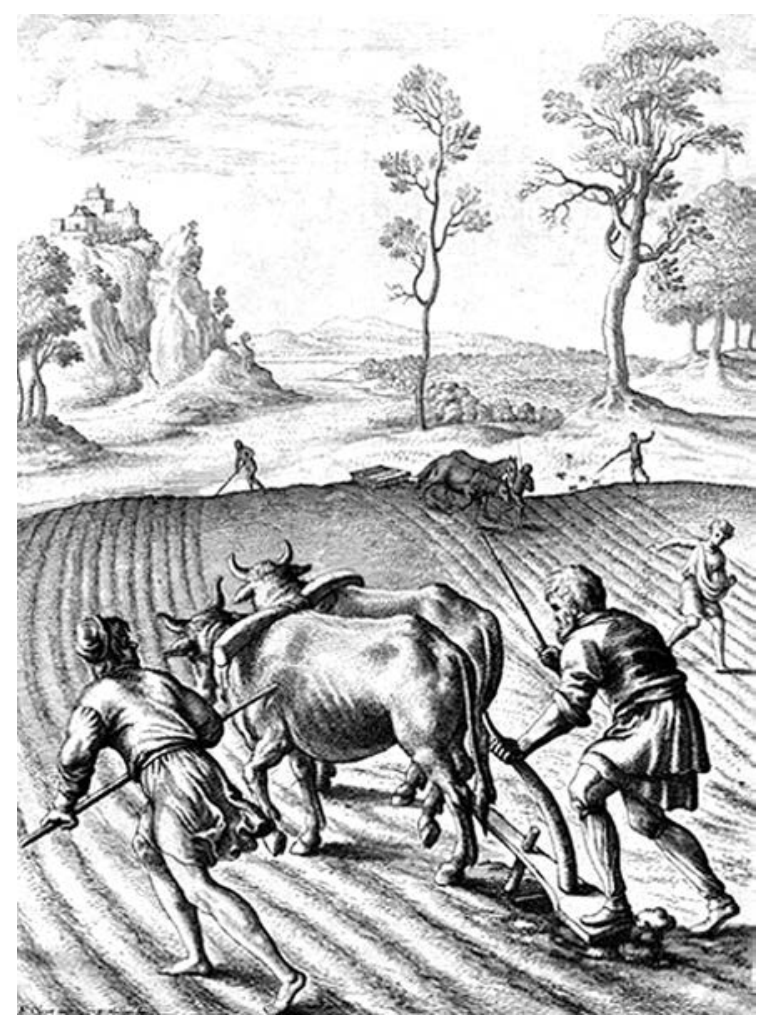

\section{ANSI吹e沾}

Asian Network for Scientific Information 


\title{
Nutritional State and Productivity of Organic Sugarcane in Goias, Brazil
}

\author{
${ }^{1}$ Lurdineide de Araújo Barbosa Borges, ${ }^{2}$ Beata Emöke Madari, ${ }^{1}$ Wilson Mozena Leandro, ${ }^{1}$ Paulo Marçal \\ Fernandes, ${ }^{4}$ Edgar Alves da Silva, ${ }^{3}$ Márcio Ricardo da Silva and ${ }^{2}$ Mellissa Ananias Soler da Silva \\ ${ }^{1}$ School of Agronomy, Federal University of Goias, UFG, Goiânia, GO, Brazil \\ ${ }^{2}$ Researcher EMBRAPA, Rice and Bean, Santo Antônio de Goiás, GO, Brazil \\ ${ }^{3}$ Department of the Plant Jalles Machado, Goianesia, GO, Brazil \\ ${ }^{4}$ Engineer Agronomist of the Plant Jalles Machado, Goianesia, GO, Brazil
}

ARTICLE INFO

Article History:

Received: December 13, 2014

Accepted: March 20, 2015

Corresponding Author:

Lurdineide de Araújo Barbosa Borges,

School of Agronomy,

Federal University of Goias,

UFG, Goiânia, GO, Brazil

\begin{abstract}
A B S T R A C T
In order to study the effect of use organic agriculture avoids the use of synthetic fertilizers and emphasizes the use of organic inputs to provide nutrients to the plants. This study had as aim to evaluate the effect of organic management time on nutrition and productivity of sugarcane. The nutrition levels and the productivity of sugarcane plantations were evaluated in areas cultivated for two, six and ten years in the organic production system compared with a sugarcane plantation cultivated for ten years in the conventional system. The sugarcane organic production system enhanced the nutrition levels of the plants and raised the crops productivity. After ten years of organic cultivation, there was an increase of $43,42.8$ and $32 \%$ in the leaf contents of potassium $(\mathrm{K})$, phosphorus $(\mathrm{P})$ and nitrogen $(\mathrm{N})$, respectively, in relation to the conventional production system and an increase of $209 \%$ in the sugarcane productivity. The management of the fertilizers inputs used in the sugarcane organic production system is adequate for the plants nutrition, with positive result on the crops productivity. The effects are more visible after six and ten years of management in the organic production system. In the organic production system, after ten and six years, it could be suggested that the productivity was 209 and $98 \%$ higher in comparison to the productivity of the cane cultivated under the conventional system, areas Org. 10 and Org.6, respectively.
\end{abstract}

Key words: Organic farming, organic fertilizer, plant nutrition, Saccharum spp., nutrients

\section{INTRODUCTION}

Brazil is a world leader in the production of sugarcane (Saccharum spp.), one of the crops of highest social, economical and environmental importance. According to Companhia Nacional de Abastecimento (Conab-Companhia Nacional de Abastecimento, 2014) in the harvest 2012/2013 Brazil produced 588.92 million tons of cane, in an area of $8,799.150$ thousand hectares. The crop is the main input to the sugar production. In the crop year 2012/2013 Brazil produced $38.34 \mathrm{Mt}$ of sugar, with a forecast increase of $6.88 \%$ for the next harvest (2013/2014). The state of Goias is one of the four biggest producers of sugarcane in Brazil and the expectation for next years is for expanding its crop area even more. The crop continues its expansion in the country and Goias. In
Brazil, the prevailing production system of sugarcane is still the conventional one. This production system plays an important role in supplying food and fibers for world markets but it is highly dependable of synthetic fertilizers (Tu et al., 2006). On the other hand, the organic agriculture avoids the use of synthetic fertilizers and emphasizes the use of organic inputs to provide nutrients to the plants (Araujo et al., 2008). Organic production system can be a viable alternative when a more sustainable system is aimed. According to the Brazilian Ministry of Agriculture (MAPA., 2003) Livestock and Food Supply, the organic production system adopts techniques to optimize the use of natural and socioeconomic resources available in order to reduce the dependence on non-renewable energy and synthetic materials. 
In the organic cultivation of sugarcane the main inputs used are agro industrial residues, such as cake filter, vinasse, organic compound, besides green fertilization with Crotalaria juncea and when necessary the natural phosphates. These inputs are used in the conventional sugarcane production system associated with mineral fertilization as a way to maximize the productivity and reduce costs with fertilizers (De Almeida et al., 2011; Bittencourt et al., 2006; De Fravet et al., 2010; Santos et al., 2010). However, there are no studies on the effect of these inputs in the organic production system of sugarcane. One of the ways to investigate its effect is by chemical analysis of foliage which affects directly in the crop productivity. This is an adequate indicator whenever there is a need to investigate, if the adopted management is coherent to the plant requirement. It constitutes an important tool to correct the crop nutritional im balances and to enhance the fertilization management over the time.

Evaluating the nutritional state of plants means in comparing the sample to a standard, that is, a plant that shows, in its tissue, all the macro and micronutrients in quantities and proportions which do not limit their growth and production (Malavolta et al., 1997). According to Reis and Monnerat (2003) the adequate foliage levels of nutrients for sugarcane are: $13.4 \mathrm{~g} \mathrm{ha}^{-1}$ of $\mathrm{N}, 1.91 \mathrm{~g} \mathrm{ha}^{-1}$ of $\mathrm{P}, 12.2 \mathrm{~g} \mathrm{ha}^{-1}$ of $\mathrm{K}$, $2.99 \mathrm{~g} \mathrm{ha}^{-1}$ of $\mathrm{Ca}, 2.15 \mathrm{~g} \mathrm{ha}^{-1}$ of $\mathrm{Mg}, 1.61 \mathrm{mg} \mathrm{ha}^{-1}$ of $\mathrm{S}$, $4.48 \mathrm{mg} \mathrm{ha}^{-1}$ of $\mathrm{Cu}, 67.8 \mathrm{mg} \mathrm{ha}^{-1}$ of $\mathrm{Mn}$ and $11.7 \mathrm{mg} \mathrm{ha}^{-1}$ of $\mathrm{Zn}$. One of the aims of this study was to evaluate the nutritional state of the sugarcane over a time period of organic cultivation.

Chemical foliage analysis and productivity of sugarcane under a conventional production system were studied by several authors. Santos et al. (2011) and De Fravet et al. (2010) verified that cake filter provides a more adequate nutrition for sugarcane and it could partially substitute mineral fertilizers and raise productivity.

De Almeida et al. (2011) found that sugarcane plants responded positively to fertilization with cake filter which raised accumulation of $\mathrm{P}, \mathrm{K}$ and $\mathrm{Cu}$ in the aerial part of the plants, with gain in the sugarcane productivity. Ambrosano et al. $(2011,2013)$ observed that the Crotalaria juncea shows potential for an adequate nitrogenous nutrition of the sugarcane, besides providing the best cost-effectiveness relation to be used in cultivation prior to the cane plantation. Ambrosano et al. (2011, 2013), Miranda et al. (2011) and Prellwitz and Coelho (2011) verified that the Crotalaria juncea is important for sugarcane nutrition with a substantial increase in its production. Marques et al. (2005) found that mineral fertilization substitution by vinasse did not intervene in the sugarcane productivity. Da Silva et al. (2014) concluded that vinasse use in sugarcane cultivation shows potential for an increase of productivity. De Barros et al. (2010) observed that adding vinasse to sugarcane crop for ten years improved the macronutrients availability but reduced micronutrients one (Duarte and Coelho, 2008; Do Vale et al., 2011), found through nutrition diagnosis the main limiting nutrients for sugarcane productivity.

Knowing the effects of inputs used in the organic production system is important, since providing disproportionate amount of nutrients may cause either a decline in productivity or a lowering in a specific nutrient level of the plant. Ambrosano et al. (2013) and Miranda et al. (2011) found that using only Crotalaria juncea as green fertilization reduced significantly the sugarcane production. Miranda et al. (2011) observed that there is an association between Crotalaria and the organic compound in sugarcane nutrition, enabling an increase of productivity. Penso et al. (1982) verified that a mixture of cake filter and natural phosphates improves the solubility of these compounds, making phosphorus available more rapidly, in comparison with its application without the cake filter. Santos et al. (2012) observed a substantial increase of the efficiency index of natural phosphates, being that the efficiency of Itafós phosphate went from $43-79 \%$ from the first to the third cut. The effects over time need to be evaluated (Ambrosano et al., 2013). More technical studies about the use of organic material (cake filter and vinasse) are necessary to raise productivity and longevity of sugarcane plantation (Rapassi et al., 2009).

The hypothesis of this study is that with the organic management of the sugarcane production, different from the conventional management, there are positive interactions between the applied organic inputs and the natural fertilizers, resulting in a positive effect over the plants nutrition and the crops productivity. In order to test this hypothesis, this study aimed to evaluate the nutrition and the productivity of sugarcane crops cultivated for two, six and ten years in the organic system production and an area cultivated for ten years in the conventional production system.

\section{MATERIALS AND METHODS}

Site and experimental treatments: The data was collected in February 2011, in sugarcane commercial cultivations from Usina Jalles Machado, Goianesia, Goias state. The climate of the region is classified, according to Köppen as savanna tropical, hot and humid, with dry winter and rainy summer (Aw) and average rainfall of $1500 \mathrm{~mm}$. Soil of the areas in this study was characterized as Rhodic Hapludox (Embrapa-Empresa Brasileira de Pesquisa Agropecuaria, 2006). Data from the soil chemical analysis in the areas under study is shown in Table 1.

The aim of this study was to evaluate the nutritional state and productivity of sugarcane cultivations on organic and conventional production systems. Four areas were selected to perform the study: (a) Area Org.2 cultivated for two years in the organic system, with coordinates S15.27832 and W048.88778, at $613 \mathrm{~m}$ above sea level; (b) Area Org.6 cultivated for six years in the organic system (S15.23079 W048.92845 and $573 \mathrm{~m}$ high); (c) Area Org. 10 with ten years of cultivation under the organic system (S15.23629 W048.97992 and $607 \mathrm{~m}$ altitude) and the (d) Conv. area cultivated for ten years on the conventional production system (S15.17917, W048.87928 and $582 \mathrm{~m}$ altitude). All the organic areas are certified as organic properties by the Instituto Biodinâmico de Certificações (IBD). The studied areas were under the same topographic, climate and soil conditions, 
Table 1: Chemical and physical analysis of the soils used in the study

\begin{tabular}{|c|c|c|c|c|c|c|c|c|c|c|c|c|c|}
\hline Areas & $\mathrm{OM}\left(\mathrm{g} \mathrm{dm}^{-3}\right)$ & $\mathrm{N}\left(\mathrm{g} \mathrm{kg}^{-1}\right)$ & $\mathrm{P}\left(\mathrm{mg} \mathrm{kg}^{-1}\right)$ & $\mathrm{K}\left(\mathrm{cmol}_{c}\right)$ & $\mathrm{Ca}\left(\mathrm{dm}^{-3}\right)$ & $\mathrm{Mg}$ & CEC & $\mathrm{H}+\mathrm{Al}$ & $\mathrm{pH} \mathrm{CaCl}$ & $\mathrm{V}(\%)$ & Sand $\left(\mathrm{g} \mathrm{kg}^{-1}\right)$ & Silt & Clay \\
\hline \multicolumn{14}{|c|}{$0-20 \mathrm{~cm}$} \\
\hline Conv. & 11.0 & 1.3 & 21.79 & 0.12 & 1.58 & 0.96 & 4.27 & 1.61 & 5.20 & 57.76 & 381 & 168 & 451 \\
\hline Org.2 & 18.2 & 1.0 & 21.54 & 0.14 & 2.27 & 0.91 & 5.04 & 1.73 & 5.26 & 63.07 & 257 & 205 & 538 \\
\hline Org.6 & 13.4 & 0.8 & 24.57 & 0.47 & 2.19 & 1.20 & 5.41 & 1.55 & 5.41 & 62.68 & 533 & 119 & 348 \\
\hline Org.10 & 24.0 & 1.5 & 34.48 & 0.81 & 4.11 & 1.34 & 7.94 & 1.68 & 5.87 & 68.48 & 296 & 198 & 506 \\
\hline \multicolumn{14}{|c|}{$20-40 \mathrm{~cm}$} \\
\hline Conv. & 7.9 & 1.2 & 5.60 & 0.11 & 1.03 & 0.88 & 3.53 & 1.51 & 5.30 & 52.79 & 366 & 180 & 454 \\
\hline Org.2 & 13.3 & 0.7 & 10.13 & 0.07 & 1.44 & 0.64 & 3.92 & 1.78 & 5.11 & 51.48 & 260 & 200 & 540 \\
\hline Org.6 & 7.1 & 0.6 & 7.71 & 0.40 & 1.16 & 0.79 & 4.02 & 1.66 & 5.29 & 48.75 & 526 & 100 & 369 \\
\hline Org.10 & 16.6 & 1.0 & 24.46 & 0.62 & 2.11 & 0.87 & 5.12 & 1.52 & 5.65 & 57.83 & 272 & 127 & 601 \\
\hline
\end{tabular}

OM: Organic matter, N: Nitrogen, P: Phosphorus, K: Potassium, Ca: Calcium, Mg: Magnesium, CEC: Cation exchange capacity, H+Al: Exchang eable acidity, V: Base saturation, cultivated in organic production system for ten years (Org.10), six years (Org.6) and two years (Org.2) and in conventional production system (Conv)

similar to each other in relation to the terrain $\left(<8^{\circ}\right)$, climate and original vegetation, differing only in relation to the production system (organic or conventional) and time of cultivation. The harvest is mechanized, without burn of the straw.

History of areas under study: The management of the conventional area was done according to the standard of the mill. In the beginning of cultivation in 2001 and in the sugarcane crop reform in 2006 , were applied $1.5 \mathrm{Mg} \mathrm{ha}^{-1}$ of dolomitic limestone, PRNT $85 \%$, incorporated with plow; $1000 \mathrm{~kg} \mathrm{ha}^{-1}$ of thermal phosphate magnesium $\left(170 \mathrm{~kg} \mathrm{ha}^{-1}\right.$ of $\mathrm{P}_{2} \mathrm{O}_{5}, 200 \mathrm{~kg} \mathrm{ha}^{-1}$ of Ca, $70 \mathrm{~kg} \mathrm{ha}^{-1}$ of $\mathrm{Mg}, 40 \mathrm{~kg} \mathrm{ha}^{-1}$ of $\mathrm{S}$ and $90 \mathrm{~kg} \mathrm{ha}^{-1}$ of Si). The phosphate was applied before the planting, throwing sowing in total area and incorporated through disking. After applying phosphate, in 2001 and 2006, soil was cultivated with Crotalaria juncea for 60 days which was rotated down superficially with help of a disk. Right after a plying was done and planting of the sugarcane. In the planting were applied $400 \mathrm{~kg} \mathrm{ha}^{-1}$ of formulation $04-28-20+0.4 \%$ of $\mathrm{Zn}$ in the planting furrow plus $50 \mathrm{~kg} \mathrm{ha}^{-1}$ of $\mathrm{N}$ (liquid urea) and $120 \mathrm{~kg} \mathrm{ha}^{-1}$ of $\mathrm{K}_{2} \mathrm{O}$ (liquid $\mathrm{KCl}$ ). The fertilization of sugarcane stump in the years of 2002, 2003, 2004, 2005, 2007, 2008 and 2009 was done by applying $50 \mathrm{~kg} \mathrm{~N} \mathrm{ha}^{-1}, 35 \mathrm{~kg} \mathrm{P}_{2} \mathrm{O}_{5}$ and $125 \mathrm{~kg} \mathrm{ha}^{-1} \mathrm{~K}_{2} \mathrm{O}$, in the line of cultivation and in 2010 it was applied $4.5 \mathrm{Mg} \mathrm{ha}^{-1}$ of poultry litter $\left(2.84 \%\right.$ of $\mathrm{P}_{2} \mathrm{O}_{5}, 2.8 \%$ of $\mathrm{N}$ and $3.9 \%$ of $\left.\mathrm{K}\right)$. In the organic areas, in the planting years and sugarcane crop reform, it was applied $1.5 \mathrm{Mg} \mathrm{ha}^{-1}$ of dolomitic limestone PRNT $85 \%$, incorporated through plowing; $1000 \mathrm{~kg} \mathrm{ha}^{-1}$ of natural phosphate of Itafós ( $8 \% \mathrm{P}_{2} \mathrm{O}_{5}, 20 \% \mathrm{CaO}, 1 \% \mathrm{MgO}$ e $3 \% \mathrm{SO}_{4}$ ). Phosphate was applied before planting, by throwing sowing and incorporated through disking. After application of phosphate, the soil was cultivated with Crotalaria juncea for 60 days which was rotated down superficially with help of a disk. Right after a plying was done and planting of the sugarcane. In the planting were applied $30 \mathrm{Mg} \mathrm{ha}^{-1}$ of cake filter (71.4\% humidity, $9.4 \mathrm{~g} \mathrm{~kg}^{-1}$ of $\mathrm{P}, 1.4 \mathrm{~g} \mathrm{~kg}^{-1}$ of $\mathrm{K}$, $34.1 \mathrm{~g} \mathrm{~kg}^{-1}$ of $\mathrm{Ca}, 9.8 \mathrm{~g} \mathrm{~kg}^{-1}$ of $\mathrm{Mg}, 6.6 \mathrm{~g} \mathrm{~kg}^{-1}$ of $\mathrm{S}$, $8.0 \mathrm{mg} \mathrm{kg}^{-1}$ of $\mathrm{B}, 22.6 \mathrm{mg} \mathrm{kg}^{-1}$ of $\mathrm{Cu}, 5,426 \mathrm{mg} \mathrm{kg}^{-1}$ of Fe, $785 \mathrm{mg} \mathrm{kg}^{-1}$ of $\mathrm{Mn}$ and $110 \mathrm{mg} \mathrm{kg}^{-1}$ of $\mathrm{Zn}$ ). The fertilization of sugarcane stumps was done by applying $8 \mathrm{Mg} \mathrm{ha}^{-1}$ of organic compound (mixture of cake filter, bagasse and ashes with $0.895 \%$ of $\mathrm{N}, 1.58 \%$ of $\mathrm{P}_{2} \mathrm{O}_{5}, 0.11 \%$ of $\mathrm{K}_{2} \mathrm{O}, 0.825 \%$ of
$\mathrm{Ca}, 0.285 \%$ of $\mathrm{Mg}, 712 \mathrm{mg} \mathrm{kg}^{-1}$ of $\mathrm{Fe}, 36$ of $\mathrm{mg} \mathrm{kg}^{-1} \mathrm{Mn}$, $51 \mathrm{mg} \mathrm{kg}^{-1}$ of $\mathrm{Zn}$ and $5 \mathrm{mg} \mathrm{kg}^{-1}$ of $\mathrm{Cu}$ ) (Dos Santos et al., 2009) and $600 \mathrm{~m}^{3} \mathrm{ha}^{-1}$ of vinasse $\left(23.2 \mathrm{mg} \mathrm{L}^{-1}\right.$ of $\mathrm{P}$ total, $24.8 \mathrm{mg} \mathrm{L}^{-1}$ of Ca, $1,199 \mathrm{mg} \mathrm{L}^{-1}$ of $\mathrm{K}, 8.2 \mathrm{mg} \mathrm{L}^{-1}$ of $\mathrm{Mg}$, $0.1 \mathrm{mg} \mathrm{L}^{-1}$ of $\mathrm{Cu}, 0.2 \mathrm{mg} \mathrm{L}^{-1}$ of $\mathrm{Zn}, 25.2 \mathrm{mg} \mathrm{L}^{-1}$ of Fe, $0.9 \mathrm{mg} \mathrm{L}^{-1}$ of $\mathrm{Mn}$ and $117 \mathrm{mg} \mathrm{L}^{-1}$ of $\mathrm{N}$ total). Area Org.2 received a planting fertilization in 2008 and two ratoon cane fertilizations in the years 2009 and 2010. Area Org.6 received a planting fertilization in 2008 and six ratoon cane fertilizations in 2004, 2005, 2006, 2007, 2009 and 2010. Area Org. 10 received two planting fertilizations in 2003 and 2008 and 9 ratoon cane fertilizations in 2000,2001, 2002, 2004 , 2005, 2006, 2007, 2009 and 2010.

Samplings and laboratory procedures: Five samplings were taken from each area (five repetitions) in an area of approximately a hectare. The sugarcane nutritional state (third cut) was evaluated at the time of full development of the crop, February 2011, by foliage sampling +1 (Malavolta et al., 1997) and then determination of nutrient concentrations was done. Each sample was made of 20 leaves picked randomly in an area of approximately one hectare. Of the leaves sampled, the chemical analysis was made on the centered $20 \mathrm{~cm}$, dispensing the central vein. These samples were submitted to drying on greenhouses at $70^{\circ} \mathrm{C}$ with forced circulation of air during $72 \mathrm{~h}$ and ground in a Wiley mill (with 20 mesh sieves). There were analyzed nitrogen levels $(\mathrm{N})$, by Nessler method (Jackson, 1965), after dry material digestion $(0.1 \mathrm{~g})$ with concentrated $\mathrm{H}_{2} \mathrm{SO}_{4}(1.5 \mathrm{~mL})$ and $\mathrm{H}_{2} \mathrm{O}_{2} 30 \%(1 \mathrm{~mL})$; the level of phosphorus $(\mathrm{P})$, colorimetrically by molybdate method; potassium level $(\mathrm{K})$ by flame emission atomic spectrophotometry; calcium levels $(\mathrm{Ca})$, magnesium $(\mathrm{Mg})$, zinc $(\mathrm{Zn})$ and copper $(\mathrm{Cu})$, by atomic absorption spectrophotometry and the sulphur level (S), by turbidimetry after digestion of dry material $(0.5 \mathrm{~g})$ with nitric acid $65 \%(4 \mathrm{~mL})$ and perchloric acid 70\% (2 mL). In order to determine the sugarcane productivity the number of stalks was counted in $20 \mathrm{~m}$ linearly. Next ten plants were collected, taking off the straws and the tips. The plants were cut near the soil, in the same way it is done during harvest and the weight of the material was measured still in the field. By knowing the number and the weight, of stalks, in each hectare, the sugarcane productivity was calculated $\left(\mathrm{Mg} \mathrm{ha}^{-1}\right)$. 
Statistical analysis: The statistical analysis was done considering a completely randomized design with five repetitions and four treatments, (areas Org.2, Org.6, Org.10 and Conv). F-test was used for variance analysis and Tukey test at $5 \%$ probability for mean comparisons.

\section{RESULTS AND DISCUSSION}

The F-values as well as the significance levels of the nutrition attributes and sugarcane productivity in the studied areas can be seen in Table 2 .

Nitrogen: The organic cultivation of the sugarcane, after six and ten years (Org.6 and Org.10), provided leaf levels of nitrogen of 32 and $15 \%$, respectively, superior to the conventional cultivation (Fig. 1). Only in these areas, the levels of nitrogen in the leaves were in the considered adequate interval of $18-21 \mathrm{~g} \mathrm{~kg}^{-1}$ proposed by Malavolta et al. (1997) and Raij etal. (1996). However, in all the areas the leaf levels of $\mathrm{N}$ were superior to the proposed by Reis and Monnerat (2003) for sugarcane crops of high productivity, in agreement with Duarte and Coelho (2008). Regarding the cane with two years under organic cultivation, it did not show leaf levels of $\mathrm{N}$ significantly different from the conventional one. According to Borges et al. (2014), because the substitution of the conventional cultivation of sugarcane by the organic system recovers the levels of $\mathrm{N}$ in the soil microbial biomass and improves the recycling of the nutrients relatively to the conventional production system.

Phosphorus: Data about phosphorus concentration showed that after ten years of organic cultivation there was an increase of $48.2 \%$ in the leaf levels of this nutrient, compared to the conventional cultivation (Fig. 2). The leaf levels of phosphorus in this area were above the interval of $2.0-2.4 \mathrm{~kg}^{-1}$, then considered adequately (Malavolta et al., 1997). The leaf concentration of $\mathrm{P}$ in the areas with six and two years of organic cultivation did not differ significantly from the conventional area. These results are related to the efficiency of the natural phosphates which increases proportionally with time after their application in soil (Santos et al., 2012) and due to the use of cake filter. Phosphorus present in the cake filter is released gradually providing a mean residual effect in the soil (Santos et al., 2010). According to Santos et al. (2010), the cake filter improves the solubility of the natural phosphates, providing phosphorus more rapidly, reducing its fixation, when in comparison to the nutrient application without the cake filter. In the conventional area, where soluble phosphate is used, the leaf concentration was low. This is due, possibly, because the sources of soluble phosphorus lose efficiency, with time, occurring adsorption or fixation of this element by the soil (Korndorfer et al., 1989). According to De Fravet et al. (2010), the reaction of the organic matter of the cake filter strengthens the nutrients absorption.

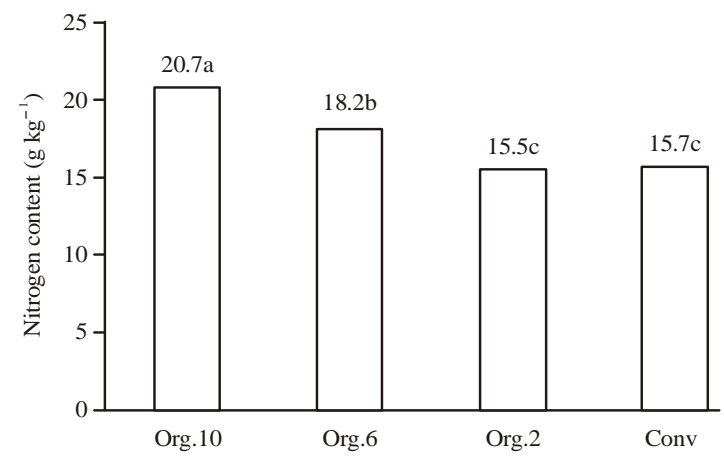

Fig. 1: Leaf nitrogen concentration $\left(\mathrm{N} \mathrm{g} \mathrm{kg}^{-1}\right)$ in plants of sugarcane cultivated in organic production system for ten years (Org.10), six years (Org.6), two years (Org.2) and in conventional production system (Conv)

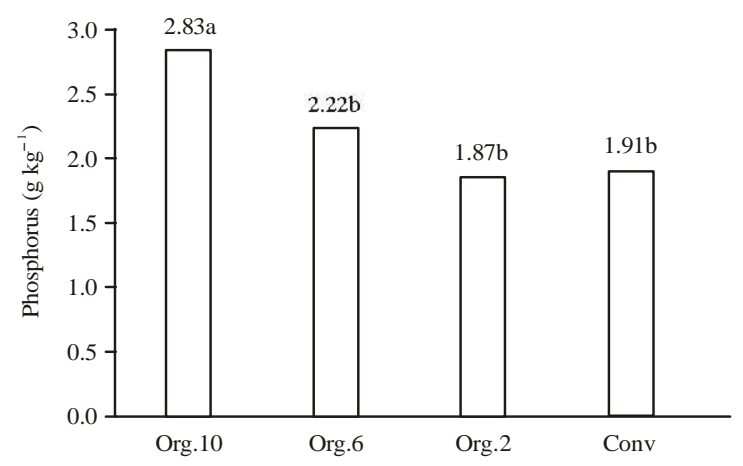

Fig. 2: Leaf phosphorus concentration $\left(\mathrm{Pg} \mathrm{kg}^{-1}\right)$ in plants of sugarcane cultivated in organic production system for ten years (Org.10), six years (Org.6), two years (Org.2) and in conventional production system (Conv)

Table 2: Summary of analysis of variance of nutrition and productivity attributes of sugarcane cultivated in organic and conventional system

\begin{tabular}{lc}
\hline Attributes & F-value \\
\hline Nitrogen (N) & $28.72^{* * * * * *}$ \\
Phosphorus (P) & $17.26^{* * * * *}$ \\
Calcium (Ca) & $0.836 \mathrm{~ns}$ \\
Magnesium (Mg) & $0.647 \mathrm{~ns}$ \\
Potassium (K) & $8.903^{* * * *}$ \\
Iron (Fe) & $3.932^{* *}$ \\
Zinc (Zn) & $3.962^{* *}$ \\
Copper (Cu) & $7.096^{* * *}$ \\
Manganese (Mn) & $19.89^{* * * * *}$ \\
Productivity & $63.39^{* * * * *}$ \\
\hline
\end{tabular}

**********:Significant at $0.1,1$ and $5 \%$ of probability, respectively. ns: Not significant. by the F-test

According to De Almeida et al. (2011), the cake filter has a positive effect as phosphorus provider to the plants. Those authors inform that sugarcane plants responded favorably to fertilization with cake filter which increased the quantity of $P$, $\mathrm{K}$ and $\mathrm{Cu}$ in the plants aerial parts. De Almeida et al. (2011) observed that cake filter, in the absence of mineral fertilization, promoted significant increments in the sugarcane leaf levels of $\mathrm{P}$. 

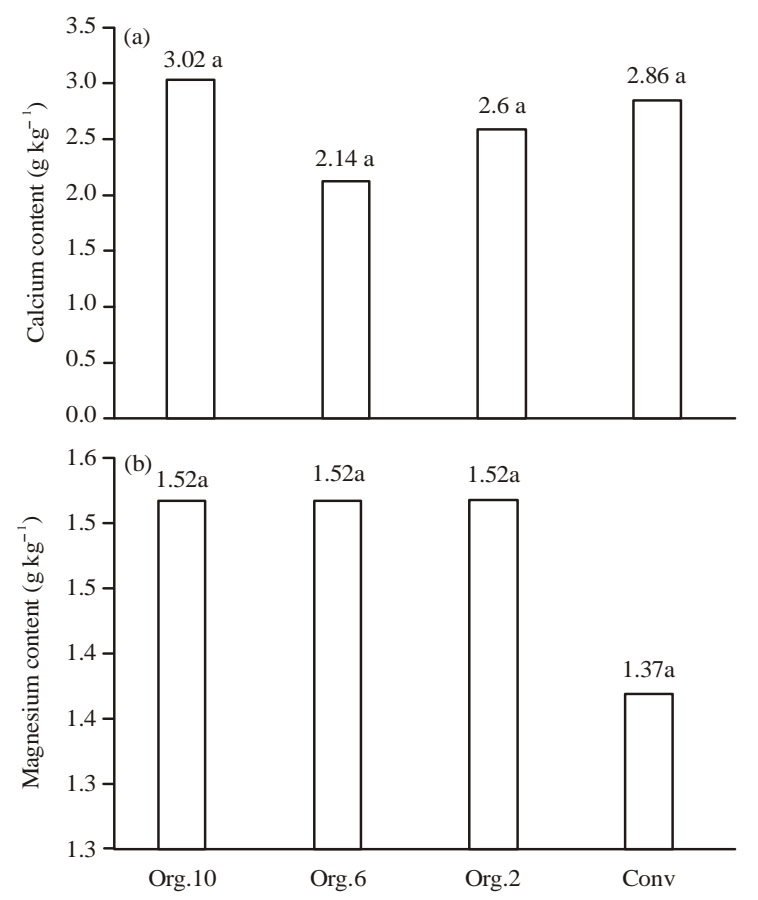

Fig. 3(a-b): Calcium (Ca) and magnesium (Mg) content in the leaves of sugarcane cultivated in organic production system for ten years (Org.10), six years (Org.6), two years (Org.2) and in conventional production system (Conv)

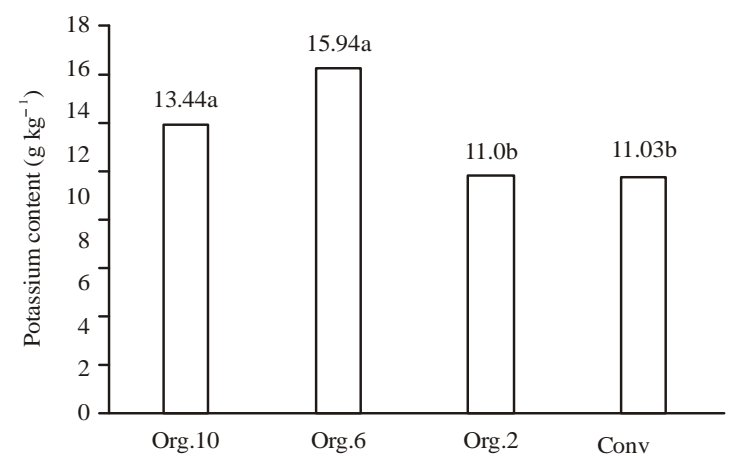

Fig. 4: Potassium $(\mathrm{K})$ content in the leaves of sugarcane cultivated in organic production system for ten years (Org.10), six years (Org.6), two years (Org.2) and in conventional production system (Conv)

Calcium (Ca) and Magnesium (Mg): For the leaf levels of $\mathrm{Ca}$ and $\mathrm{Mg}$ of sugarcane there were not significant differences among the production systems (Table 2). In general, the foliar levels of Calcium vary from $2.14-3.02 \mathrm{~g} \mathrm{~kg}^{-1}$ (Fig. 3). This shows that in all areas the foliar concentration of this nutrient is well below the adequate level cited in the literature (Malavolta et al., 1997; Malavolta, 1981; Orlando Filho and Haag, 1976). However, if using the values proposed by Reis and Monnerat (2003) of $2.99 \mathrm{~g} \mathrm{~kg}^{-1}$, the area Org.10 is in the adequate level. Considering Magnesium, the concentration

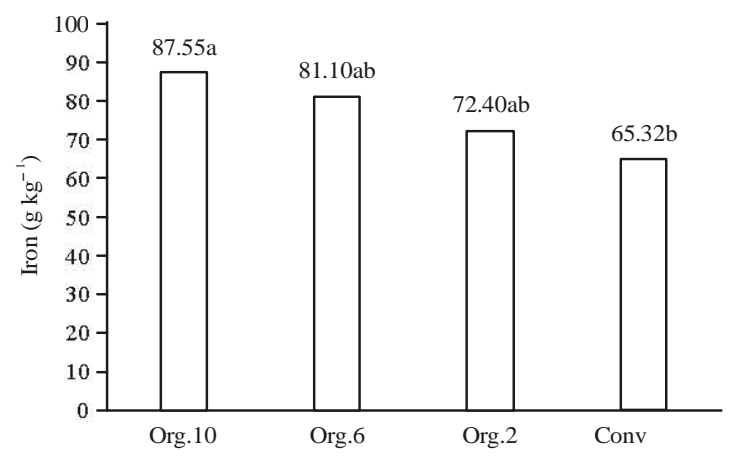

Fig. 5: Iron (Fe) content in the leaves of sugarcane cultivated in organic production system for ten years (Org.10), six years (Org.6), two years (Org.2) and in conventional production system (Conv)

varied from $1.37-1.52 \mathrm{~g} \mathrm{~kg}^{-1}$. These values are also below the adequate level for this crop of $2.00-2.15 \mathrm{~g} \mathrm{~kg}^{-1}$ cited in the literature (Malavolta et al., 1997; Malavolta, 1981; Orlando Filho and Haag, 1976; Reis and Monnerat, 2003). In the absence of mineral fertilization, De Almeida et al. (2011) observed that fertilization with cake filter tripled the $\mathrm{Mg}$ content in relation to the witness. Since Calcium competes with Potassium for the absorption sites in the plasma membrane, the high levels of Potassium in the soil and organic inputs may have influenced negatively the calcium absorption by the plants (Malavolta et al., 1997).

Potassium (K): Regarding the leaf concentration of Potassium it was noted that the area cultivated for six years in the organic system (Org.6) was statistically superior to the conventional one (Fig. 4). The amount was $44.5 \%$ higher in relation to the conventional area. The other areas did not differ significantly between each other. According to Reis and Monnerat (2003), only the areas Org. 10 and Org. 6 match the adequate value which is $12.2 \mathrm{~g} \mathrm{~kg}^{-1}$. However, according to Malavolta et al. (1997), the adequate interval varies from $11-13 \mathrm{~g} \mathrm{~kg}^{-1}$. Following this last criterion in order to interpret the leaf chemical analysis, it can be seen that the leaf concentration of potassium in all the areas are inside the adequate interval values.

Iron (Fe): In the analysis of data on iron concentration ( $\mathrm{Fe}$ ), it was noted that the difference between the production systems was only observed after ten years of organic cultivation (Org.10) (Fig. 5). There it was observed an increase of $34 \%$ in comparison to the levels in the conventional area. By looking at the data according to Malavolta et al. (1997) and Orlando Filho and Zambello Jr. (1977), only the areas Org.10 and Org. 6 would be with the leaf concentration of $\mathrm{Fe}$ in the adequate interval levels of $80-150 \mathrm{mg} \mathrm{kg}^{-1}$, considered adequate by those authors. However, as stated by Malavolta (1981) and Orlando Filho et al. (1979), all the areas would be with the iron concentration well below the appropriate levels for this crop that should be between $100-392 \mathrm{mg} \mathrm{kg}^{-1}$. 


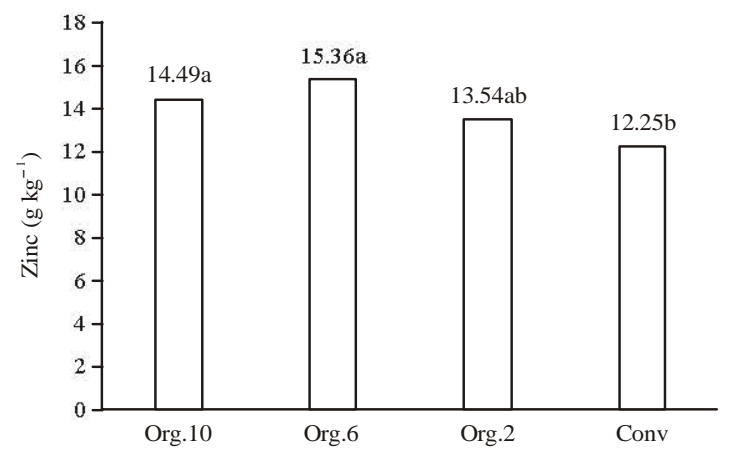

Fig. 6: Zinc $(\mathrm{Zn})$ content in the leaves of sugarcane cultivated in organic production system for ten years (Org.10). six years (Org.6). two years (Org.2) and in conventional production system (Conv)

Zinc (Zn): Regarding the leaf levels of zinc (Zn), it was observed that the area with six years of organic cultivation (Org.6) showed the highest concentrations, being $25.4 \%$ above the level of the conventional area. In all the areas, the leaf concentration of zinc varied from $12.25-15.36 \mathrm{mg} \mathrm{kg}^{-1}$ (Fig. 6). These concentrations are well below the appropriate interval levels of 23 to $24 \mathrm{mg} \mathrm{kg}^{-1}$ (Orlando Filho et al., 1980) and $25-50 \mathrm{mg} \mathrm{kg}^{-1}$ (Malavolta et al., 1997). However, the zinc levels were above $10 \mathrm{mg} \mathrm{kg}^{-1}$ (Malavolta, 1981) and of $11.7 \mathrm{mg} \mathrm{kg}^{-1}$ (Reis and Monnerat, 2003) referred as adequate for those authors. Thus, by using the criteria proposed by those last authors to interpret the leaf chemical analysis, it can be said that the leaf level of zinc is appropriate but according to other authors, the Zn levels in sugarcane leaves are featured as limiting factors of productivity. In a study by Reis and Monnerat (2003), with 126 samples collected in sugarcane fields cultivated in the conventional system, they observed that $99.2 \%$ of the samples showed levels of this nutrient below those considered adequate for this crop.

Copper (Cu): Considering the cooper levels $(\mathrm{Cu})$ it was noticed that by leaving the conventional production system to the organic, in the first years of cultivation (Org.2) there was a reduction of $20.7 \%$ in comparison to the conventional (Fig. 7), being below the critical level for the sugarcane (Malavolta et al., 1997; Malavolta, 1981; Orlando Filho et al., 1980; Reis and Monnerat, 2003) but after six years of organic cultivation the levels were restored to the interval considered appropriate for the crop. Reis and Monnerat (2003), in a study with 126 samples collected in sugarcane fields in the city of Campos dos Goytacazes (RJ, Brazil), observed that $98.4 \%$ of the samples showed a lack of copper. Following the study of De Almeida et al. (2011) an application of $113 \mathrm{Mg} \mathrm{ha}^{-1}$ of cake filter would be sufficient to provide the nutritional requisites of copper for the sugarcane which could be an alternative in the supply of this nutrient for some regions of Brazil considered poor of micronutrients.

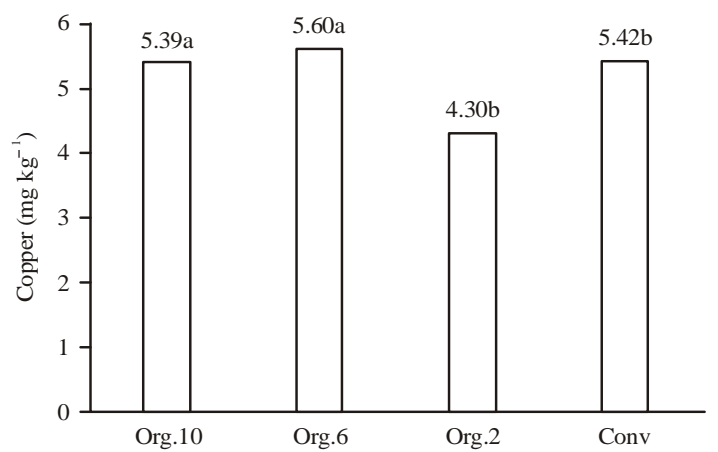

Fig. 7: Copper $(\mathrm{Cu})$ content in the leaves of sugarcane cultivated in organic production system for ten years (Org.10). six years (Org.6). two years (Org.2) and in conventional production system (Conv)

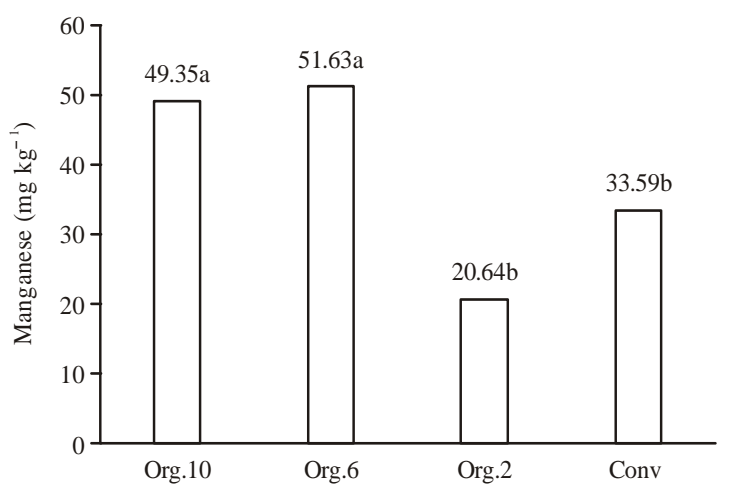

Fig. 8: Manganese $(\mathrm{Mn})$ content in the leaves of sugarcane cultivated in organic production system for ten years (Org.10), six years (Org.6), two years (Org.2) and in conventional production system (Conv)

Manganese (Mn): Regarding the manganese (Mn), it was observed that there was a tendency of reduction in the leaf concentration of this nutrient in the first years of organic cultivation (Fig. 8). However, after six (Org.6) and ten (Org.10) years of organic cultivation, the levels raised overcoming in 53.7 and $47.9 \%$, respectively, the leaf concentration of the conventional production system. In this study, only the area with six years of organic cultivation (Org.6) showed leaf levels of $\mathrm{Mn}$ inside the interval of $50-125 \mathrm{mg} \mathrm{kg}^{-1}$, considered adequate for sugarcane according to Malavolta et al. (1997). However, if using the criterion given by (Malavolta, 1981; Reis and Monnerat, 2003), it can be noted that all the areas have this nutrient concentration below the critical level for the sugarcane. Raising the amount of application of cake filter until $113 \mathrm{Mg} \mathrm{ha}^{-1}$, will not be sufficient to alter the content of this nutrient for cane (De Almeida et al., 2011). This may indicate that for Mn the cake filter is not the more appropriate source. The same doubt can be raised regarding the vinasse and the organic compound.

These results show that the management of the inputsused for fertilization of sugarcane (cake filter, vinasse, organic 


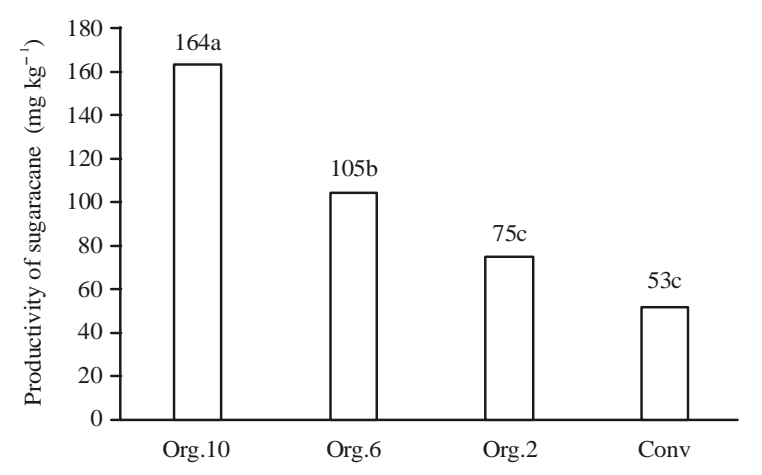

Fig. 9: Productivity of sugarcane $\left(\mathrm{Mg} \mathrm{ha}^{-1}\right)$ cultivated in organic production system for ten years (Org.10), six years (Org.6) and two years (Org.2) and in conventional production system (Conv)

compound, natural phosphate of Itafós and green fertilization with Crotalaria juncea) were effective in supplying $\mathrm{N}, \mathrm{P}, \mathrm{Ca}$, $\mathrm{K}, \mathrm{Fe}, \mathrm{Zn}$ and $\mathrm{Cu}$ to the sugarcane and that over the period of six and ten years of organic cultivation, the plants were better nourished than in the conventional system.

De Almeida Theodoro et al. (2007) obtained similar results to ours, considering organic production systems of coffee.

After ten years of organic cultivation, the plants showed to be deficient only in relation to $\mathrm{Mg}$ and $\mathrm{Mn}$. Besides the low levels of $\mathrm{Mg}$ and $\mathrm{Mn}$, the productivities were high. Possibly the criteria of interpretation for the leaf analysis for these elements should be other for organic systems consolidated by more than ten years. After six years of organic cultivation, in addition to those two elements, plants were deficient in $\mathrm{Ca}$. In the area of two years of organic cultivation, of all the elements studied, only K was not limiting. These results were similar to the observed in the conventional area, with exception of copper which was not limiting in that area. $\mathrm{Mg}$ and $\mathrm{Mn}$ were considered the most limiting nutrients, because all the crops evaluated showed levels of these nutrients below the recommended. Considering $\mathrm{Zn}$, this nutrient may or may not be limiting factor of productivity. This depends on the used source in order to interpret it.

Productivity: Considering the cane productivity, it was noted that figures in the organic areas were superior to the ones in the conventional area (Fig. 9). Overriding, considerably, the Brazilian average for conventional cultivations which is $69.4 \mathrm{Mg} \mathrm{ha}^{-1}$ (Conab-Compania Nacional de Abastecimento, 2014). There was a raise of 209 and $98 \%$ in productivity in the areas Org.10 and Org.6, respectively in comparison to the conventional one. The highest productivity, $163 \mathrm{Mg} \mathrm{ha}^{-1}$, was found in Org. 10 which can be due to the positive effect of the inputs management in the organic production system. A similar result to this was obtained by Miranda et al. (2011) in sugarcane fields where Crotalaria was used together with compound of cake filter, with productivity of $163 \mathrm{Mg} \mathrm{ha}^{-1}$. The application of cake filter also has given positive returns in sugarcane productivity in other studies (De Fravet et al., 2010; Santos et al., 2011, 2010; Dos Santos et al., 2009), possibly related to the organic matter and nutrients found in the cake filter. Possibly, there is a residual effect in the soil because of the inputs used in the organic system, since the areas cultivated for longer periods in the organic system showed leaf concentration levels of nutrients inside or above the appropriate interval for that crop. The lowest productivity was observed in the conventional area which could have happened because, the deficiency of $\mathrm{P}, \mathrm{Ca}, \mathrm{Mg}, \mathrm{Mn}$ and Fe which were below the critical levels for the crop.

\section{CONCLUSION}

The management of the inputs used in the organic production system of the sugarcane was appropriate to nourish the cane. The effects are noteworthy after six and ten years of organic production management. In this production system, after ten years (Org.10). There was an increase in the leaf concentration of potassium $(\mathrm{K})$, phosphorus $(\mathrm{P})$ and nitrogen (N), of $43,42.8$ and $32 \%$, respectively, in comparison to the conventional system. For the zinc $(\mathrm{Zn})$ and the copper $(\mathrm{Cu})$ the difference was detected after six years of organic cultivation (Org.6). Regarding the calcium (Ca) and the magnesium (Mg), it was observed that ten years of cultivation were not sufficient to detect differences between the production systems. In the organic production system, after ten and six years, the productivity was 209 and $98 \%$ higher in comparison to the productivity of the cane cultivated under the conventional system, areas Org. 10 and Org.6, respectively.

\section{ACKNOWLEDGMENTS}

The authors are grateful to the Jalles Machado Company for authorizing sampling and providing soil and crop information. The study used resources of the National Rice and Bean Research Center of the Brazilian Agricultural Research Corporation (Embrapa Rice and Bean, Project Number 03.14.00.043.00.00) and the Scientific Research Foundation of GoiÃ $j$ s State (FAPEG, Project Number 201210267001033). L. A. B. Borges, W.M. Leandro and B.E. Madari are grateful for the National Council for Research and Development of Brazil (CNPq) for providing $\mathrm{PhD}$ scholarship, DTI and PQ fellowship, respectively.

\section{REFERENCES}

Ambrosano, E.J., H. Cantarella, G.M.B. Ambrosano, E.A. Schammass and F.L.F. Dias et al., 2011. [Productivity of sugarcane after previous legumes crop]. Bragantia, 70: 810-818, (In Protuguese).

Ambrosano, E.J., H. Cantarella, F. Rossi, E.A. Schammass and E.C. da Silva et al., 2013. [Behavior of sugar cane first ratoon and green manures in intercropping system]. Revista Brasileira Agroecologia, 8: 80-90, (In Protuguese). 
Araujo, A.S.F., V.B. Santos and R.T.R. Monteiro, 2008. Responses of soil microbial biomass and activity for practices of organic and conventional farming systems in Piaui state, Brazil. Eur. J. Soil Biol., 44: 225-230.

Bittencourt, V.C., A.C. Strini, L.G. Cesarim and S.R. Souza, 2006. [Enriched cake filter]. Revista Idea News, Vol. 6, pp: 2-6, (In Portuguese).

Borges, L.D.A.B., M.L.G. Ramos, L.J. Vivaldi, P.M. Fernandes, B.E. Madari, R.A.B. Soares and P.R. Fontoura, 2014. Impact of sugarcane cultivation on the biological attibutes of an oxisol in the brazilian savannah. Biosci. J., 30: 1459-1473.

Conab-Compania Nacional de Abastecimento, 2014. Follow up of Brazilian harvest: Sugarcane. Conab, Brazil, (In Portuguese).

Da Silva, A.P.M., J.A.M. Bono and F.A.R. Pereira, 2014. [Fertigation with vinasse in sugarcane crop: Effect on the soil and on productivity]. Revista Brasileira Engenharia Agricola Ambiental, 18: 38-43, (In Portuguese).

De Almeida, Jr. A.B., C.W.A. do Nascimento, M.F. Sorbral, F.B.V. da Silva and W.A. Gomes, 2011. Soil fertility and uptake of nutrients by sugarcane fertilized with filter cake. Revista Brasileira Engenharia Agricola Ambiental, 15: 1004-1013.

De Almeida Theodoro, V.C., R.J. Guimaraes and A.N.G. Mendes, 2007. [Performance of organic management in the nutrition and productivity of the coffee crop]. Acta Scientiarum Agronomy, 29: 631-638, (In Portuguese).

De Barros, R.P., P.R.A. Vingas, T.L. da Silva, R.M. de Souza and L. Barbosa et al., 2010. [Chemical changes in soils cultivated with sugarcane and addition of vinasse]. Pesquisa Agropecuaria Tropical, 40: 341-346, (In Portuguese).

De Fravet, P.R.F., R.A.B. Soares, R.M.Q. Lana, A.M.Q. Lana and G.H. Korndorfer, 2010. [Effect of filter cake doses and methol of application on yield and technologycal quality of sugar cane ratoon]. Ciencia Agrotecnologia, 34: 618-624, (In Portuguese).

Do Vale, D.W., R.D.M. Prado, C.C. Avalhaes and R.H. Hojo, 2011. [Macronutrients omission in the nutrition and growth of sugarcane grown in nutritious solution]. Revista Brasileirade Ciencias Agrarias, 6: 189-196, (In Portuguese).

Dos Santos, V.R., G.M. Filho, A.W. Albuquerque, J.P.V. da Costa, C.G. dos Santos and A.C.I. dos Santos, 2009. [Growth and yield of sugarcane under different phosphorus sources]. Revista Brasileira Engenharia Agricola Ambiental, 13: 389-396, (In Portuguese).

Duarte, Jr. J.B. and F.C. Coelho, 2008. [Sugarcane in a no-tillage system compared to the conventional system with and without, manuring]. Revista Brasileira Engenharia Agricola Ambiental, 12: 576-583, (In Portuguese).

Embrapa-Empresa Brasileira de Pesquisa Agropecuaria, 2006. [Brazilian System of Soils Classification]. 2nd Edn., Embrapa, Brazil, (In Portuguese).
Jackson, M.L., 1965. Soil Chemical Analysis. Prentrice Hall, Englewood, Cliffs New York, USA.

Korndorfer, G., G. Vieira, J. Martins and L. Mathiesen, 1989. [Respond of the plant cane to different sources of phophorus]. Boletim Tecnico Copersucar., 45: 31-37, (In Portuguese).

MAPA., 2003. [Brazilian federal law number 10.831]. Ministerio da Agricultura Pecuaria e Abastecimento, December 23, 2003, (In Portuguese).

Malavolta, E., 1981. [Manual for Agriculture Chemistry and Fertilization]. 1st Edn., Editora Agronomica Ceres, Brazil, ISBN-13: 9788531800184, Pages: 596, (In Portuguese).

Marques, M., F. Camilotti, T.A. Marques, L. Tasso Jr. and A. da Silva, 2005. [Sugarcane cultivated with sludge, vinasse and mineral fertilizer]. Colloquium Agrariae, 1: 43-49, (In Portuguese).

Malavolta, E., G.C. Vitti and S.A. Oliveira, 1997. [Evaluation of the Nutritional State of Plants]. 1st Edn., Editora Ceres, Piracicaba, SP, Brazil, (In Portuguese).

Miranda, J.M., M.V. Rigoni and F.T. Silveira, 2011. Association of crotalaria as green manures and mineral inproductivity of sugar cane. Biosci. J., 27: 948-953.

Orlando Filho, J. and E. Zambello Jr., 1977. [Leaf diagnosis of $\mathrm{Cu}, \mathrm{Fe}, \mathrm{Mn}$ and $\mathrm{Zn}$ in 16 cultivars of sugarcane (Saccahrum sp) in different soil groups]. Revista Brasil Acucareiro., 90: 28-37, (In Portuguese).

Orlando Filho, J. and H.P. Haag, 1976. [Nutritional state of $\mathrm{N}, \mathrm{P}, \mathrm{K}, \mathrm{Ca}, \mathrm{Mg}$ and $\mathrm{S}$ in 16 cultivars of sugarcane (Saccharum spp.) by leaves analysis]. Revista Brasil Acucareiro, 88: 11-27, (In Portuguese).

Orlando Filho, J., E. Zambello Jr. and H.P. Haag, 1979. [Fe absorption by sugarcane in soils of the Sao Paulo State]. Anais da ESALQ., 36: 387-402, (In Portuguese).

Orlando Filho, J., E. Zambello Jr. and H.P. Haag, 1980. [Absorption of $\mathrm{Zn}$ by sugarcane, cultivar $\mathrm{CB} 41-76$, in tree soils of the Sao Paulo State]. Revista Brasil Acucareiro, 96: 21-30, (In Portuguese).

Penso, J.S.A., J.M. Braga and J.T.L. Thiebaut, 1982. [Evaluation of solubility of Patos phosphate III-Mixture of cake filter and vinasse]. Revista Ceres., 29: 516-525, (In Portuguese).

Prellwitz, W.P.V. and F.C. Coelho, 2011. [Productivity of stalks, leaf area index and $\mathrm{N}$ accumulation in sugarcane rattons intercropped with Crotalaria juncea L.]. Revista Ceres, 58: 773-780, (In Portuguese).

Raij, B.V., H. Cantarella, J.A. Quajjio and A.M.C. Furlani, 1996. [Recommendations for fertilization and liming for the state of Sao Paulo]. Boletin Tecnico 100, Instituto Agronomico de Campinas, (In Portuguese).

Rapassi, R.M.A., M.A.A. Tarsitano and A.C. Bolonhezi, 2009. [Technical and economic evaluation of sugar cane produc tion systems in Western Sao Paulo State]. Informacoes Economicas, 39: 11-21, (In Portuguese).

Reis, Jr. R.A. and P.H. Monnerat, 2003. [DRIS norms validation for sugarcane crop]. Pesquisa Agropecuaria Brasileira, 38: 379-385, (In Portuguese). 
Santos, D.H., C.S. Tiritan, J.S.S. Foloni and L.B. Fabris, 2010. [Sugarcane yield under fertilization with filter cake enriched with soluble phosphate]. Pesquisa Agropecuaria Tropical, 40: 454-461, (In Portuguese).

Santos, D.H., M.A. Silva, C.S. Tirtan, J.S.S. Foloni and F.R. Echer, 2011. [Technological quality of sugarcane under fertilization with filter cake enriched with soluble phosphate]. Revista Brasileira Engenharia Agricola Ambiental, 15: 443-449.
Santos, G.A., R.T.X. Sousa and G.H. Korndorfer, 2012. [Profitability depending on the use and agronomic efficiency of phosphate fertilizer applied in pre-planting of sugar]. Biosci. J., 28: 846-851, (In Portuguese).

Tu, C., F.J. Louws, N.G. Creamer, J.P. Mueller and C. Brownie et al., 2006. Responses of soil microbial biomass and $\mathrm{N}$ availability to transition strategies from conventional to organic farming systems. Agric. Ecosyst. Environ., 113: 206-215. 